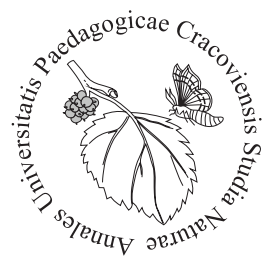

Grażyna Sroka University of Józef Dietl in Kraków, Legnicka 5 St., 31-216 Kraków, Poland; grazyna.sroka73@gmail.com

\title{
Prevention and care of diabetic foot syndrome - an assessment of respondents' competence
}

For many diseases, complications arise that could have often been prevented by earlier intervention. This is particularly relevant to complications in chronic diseases. Many disease complications start with skin damage, especially in metabolic diseases, of which diabetes is one of the most common (King et al., 1998; Karvonen et al., 2000; Zieliński et al., 2014; Benoit et al., 2020). Such damage can be countered by taking various types of preventive measures. This refers to a preventive orientation of diagnostics and treatment of complications in large disease populations. Early protection of the skin of the feet relates significantly to the prevention of disease syndromes in the course of diabetes complications (Hoffstad et al., 2015). For this reason, there is a need for planned, multi-directional skin protection. Preventive foot skin protection requires, first and foremost, quality diabetes treatment and specialised, planned leg skin hygiene (Tatoń et al., 2013). Pathological conditions of the lower limbs, that develop within the arterial, venous and lymphatic vessels, can lead to disorders in the functioning of cells, then tissues and, consequently, all of the limb structures (DiGiovani, Greisberg, 2010; Holman et al., 2012; Czeleko et al., 2014).

Diabetic foot syndrome (DFS) is an infection of the lower extremities with ulceration and/or destruction of deep tissues, occurring in conjunction with neurological disorders and peripheral vascular diseases of varying degrees. The first symptoms of DFS are numbness and tingling in the foot, followed by swelling, discoloration of the skin and changes in the appearance of nails. The feet become dry; small, difficult to heal wounds and numerous corns and calluses form on them (Wujczyk, 2009). The main risk factors for ulceration include improper levels of glucose in the body, nephropathy, improper nutrition, impaired vision, older age and, above all, improper foot hygiene (Kasperczyk, 2004).

The etiopathogenesis of DFS, one of the most common complications of diabetes, is complex. The main pathogenetic factors of this disease syndrome are peripheral is- 
chemic changes, peripheral neuropathy, mechanical factors and various types of infections. Depending on the main etiological factor, diabetic foot may be ischemic, neuropathic or mixed (Bernas, 2003; Głuszek et al., 2007). Ischemic DFS is the result of progressive diabetic angiopathy (disease of a group of arterial vessels) (Kozek, 2002). The resulting disorders are the result of atherosclerosis, sclerosis in small arterioles and degenerative changes in the capillaries of the foot tissues (Koblik, 2005; Tuttolomondo et al., 2015). The diabetic neuropathic foot syndrome develops as a result of lesions of both the somatic and autonomic peripheral nervous system. After injuries, it is the second most common cause of nerve damage (Boucek, 2006; Boulton et al., 2004; Boulton, 2006; Levy, Valabhji, 2008). Whereas, mixed DFS combines ischemic and neuropathic diabetic foot features. It results from the formation of both neuropathy and angiopathy, dependent on similar clinical factors, such as duration of diabetes, degree of metabolic control and genetic background (Koselak, 2014).

The risk of developing DFS according to Koblik $(2005,2008)$ is a concern in all patients with diabetes. Taton et al. $(2008,2013)$ are convinced that the prevention of DFS begins with the diagnosis of diabetes. They claim that early prevention of diabetic foot will protect against the risk of amputation of the lower limbs. They pay attention primarily to preventive measures, e.g. foot exercises, careful skin care and controlling blood supply and innervation. Koselak (2014) also wrote about the basis of prevention, i.e. the patient's education in the proper treatment of the DFS case. A huge role in this prevention is assigned to the podologist, who ensures proper control of the progressive destruction of the skin of the limbs (Świderska, 2012). His knowledge of various fields of medicine allows for the introduction of appropriate treatments and care products. Therefore, he should be the first to inform the patient about possible complications and to indicate methods of proper foot care.

The aim of this study was to (1) assess the practical knowledge of respondents from three age groups on the subject of prevention and care in a DFS and to (2) identify the most important areas of the podologist's work in promoting the prevention of this disease.

\section{Research methodology}

Evaluations, regarding knowledge about the care of diabetic foot, were made among 86 clients with diabetes randomly selected from a cosmetic salon in Krakow (Southern Poland) within six months of visiting the salon. The research group was divided into three age categories (Tab. 1). Unequal numbers in different age categories confirmed the fact that diabetic complications are more common in older people (Taton et al., 2013), which more often forces them to visit a podologist. 
Tab. 1. Characteristics of the statistical population taking part in the survey on feet care in diabetic foot syndrome

\begin{tabular}{|c|c|c|c|c|}
\hline \multirow{2}{*}{ Age range } & \multicolumn{2}{|c|}{ Gender } & \multirow{2}{*}{$\Sigma$} & \multirow{2}{*}{ [\%] } \\
\hline & Male & Female & & \\
\hline I - 30-50 years old & 3 & 6 & 9 & 10 \\
\hline II - 51-70 years old & 14 & 19 & 33 & 38 \\
\hline III - over 70 years old & 9 & 35 & 45 & 52 \\
\hline $\bar{\Sigma}$ & 26 & 60 & 86 & 100 \\
\hline
\end{tabular}

The study was conducted using a survey technique. In the chosen method, in order to obtain the necessary information, a research tool was used, which was appropriately designed the questionnaire of the survey. The questionnaire consisted of 35 questions investigating knowledge about feet care - how to wash, moisturise, massage, cut nails, remove layers of epidermis and use footwear, and awareness of how to control glucose, normal body weight, blood pressure and other items. The survey contains suggested questions (Appendix 1 - survey template). It was modelled on the survey of July 31, 2014, National Health Fund as Annex No. 10 to ordinance No. 88/2013/DSOZ. All respondents were informed about the aim of the research. The content of the survey and how to complete it was explained in detail to the respondents. The survey was anonymous.

In the statistical study, individual questions were assigned the following score: " +1 " point - if the answer was correct, " -1 " point - if the answer was incorrect and "0" points - if the respondent selected the answer "I do not know". By providing all correct answers, a respondent could receive a maximum of 35 points, while answering all questions incorrectly would result in the lowest score of -35 points. Based on the surveys, a comprehensive summary of all results was created in tabular form.

For the statistical analyses, the following were compared: correct, incorrect and " $\mathrm{I}$ don't know" answers given by respondents to survey questions in terms of numbers and percentages, average survey scores for men and women in the analysed statistical population, average survey score for the three age categories of respondents, the total score achieved by all respondents to survey questions, the total score of the respondents separately in the gender groups and the total score obtained by the respondents for each of the three age groups.

To test the statistical significance of the average results for the female and male groups, the student's T-test for independent groups was used. Statistical differences between the average results in three distinguished age groups of respondents were assessed using the parametric one-way ANOVA test, using Tukey's post hoc test. Statistical significance for all tests was assumed at $p \leq 0.05$. Statistical tests were performed using the Statistica v10.0 for Windows package. 


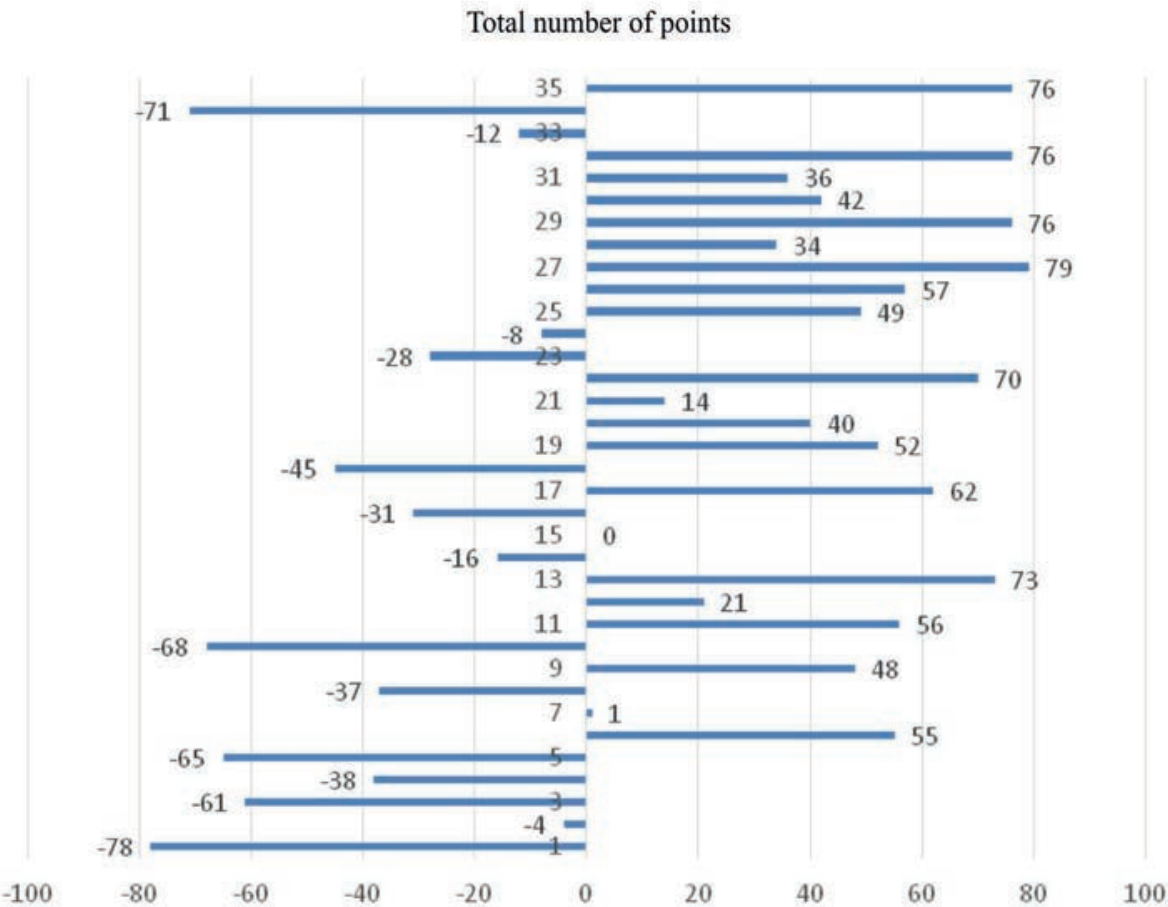

Fig. 1. Comparison of the total score obtained by all respondents on subsequent survey questions (1-35 question numbers) regarding of diabetic foot care; $\mathrm{N}$ (number of respondents) $=86$

\section{Results of study}

The numerical and percentage comparison of correct, incorrect and "I don't know" answers given by respondents to individual survey questions revealed that most people correctly believe that an important element preventing diabetic foot is to control glucose, blood pressure and maintain a healthy weight ( $94 \%$ of respondents). Respondents know about the need for thorough drying of the space between the toes in the prevention of diabetic foot ( $91 \%$ of them) and about checking the shoe before wearing it in order to avoid mechanical injuries ( $93 \%$ of them). They also know that smoking can lead to earlier development of DFS (92\% of respondents) (Appendix 2 survey summary table).

However, almost all respondents mistakenly believed that, for cutting the nail plate, it is best to use a metal clipper ( $91 \%$ of respondents); it is actually easy to damage the skin surfaces with this type of tool, which is very dangerous with a diabetic foot. Respondents were also not aware of how many times a day they can change dressings 


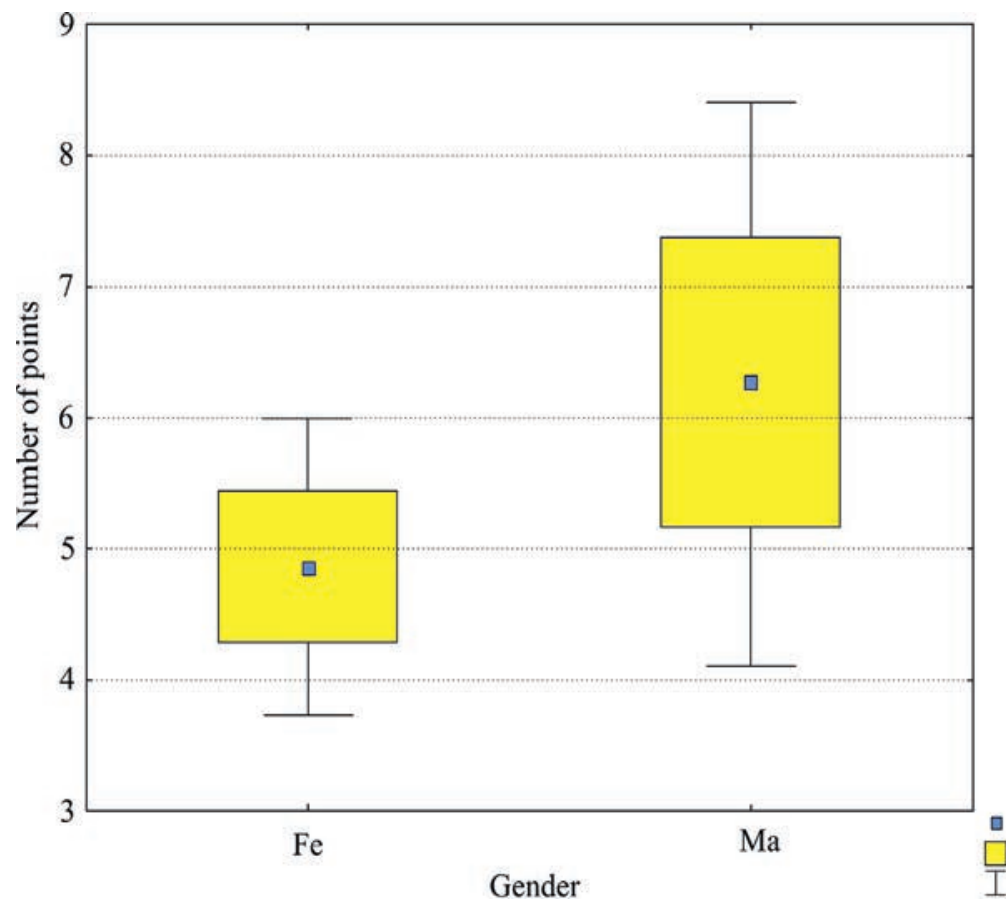

a Average

Average \pm SE

I Average $\pm 1.96 * \mathrm{SE}$

Fig. 2. Comparison of the average scoring of surveys on diabetic foot care for the groups: Fe - Females and $\mathrm{Ma}$ - Males, in the analysed statistical population; statistical significance between the examined groups was tested by the student's T test; differences were considered significant at $\mathrm{p} \leq 0.05$

in the presence of fresh ulceration ( $84 \%$ of respondents); they did not know that it is best to walk around the house in closed-toe slippers ( $88 \%$ of respondents), that they should not wear soft-soled shoes ( $80 \%$ of respondents) or that it is not advisable to moisten the space between the toes of feet with DFS (84\% of respondents) (Appendix 2 - survey summary table; Fig. 1). On questions such as: Hydro massagers should be used for foot massage; For removal of nail cuticles a special preparations should be used to dissolve them; The most important thing when checking your feet is checking the dorsal parts - almost half of the respondents answered "I don't know" (Appendix 2 - summary survey table).

A comparison of the average scores of surveys for males and females in the analysed statistical population showed that males averaged 6.27 points $(\mathrm{SD} \pm 5.57)$ and females 4.87 ( $\mathrm{SD} \pm 4.45$ ) (Fig. 2; Tab. 2). The results of the student's T-test showed no statistically significant differences in the average value of points between female and male groups $(\mathrm{p}=0.22)$. 
Tab. 2. Student T-test results for independent groups: Fe - Females, Ma - Males, $\mathrm{t}$ - test value; $\mathrm{df}-\mathrm{de}$ grees of freedom; $\mathrm{p}$ - probability value; $\mathrm{N}$ - sample count, $\mathrm{SD}$ - standard deviation; the differences were considered significant at $\mathrm{p} \leq 0.05$

\begin{tabular}{lcccccccccccc}
\hline & \multicolumn{11}{c}{ Test-T } \\
\cline { 2 - 5 } & $\begin{array}{c}\text { Average } \\
\mathrm{Fe}\end{array}$ & $\begin{array}{c}\text { Average } \\
\mathrm{Ma}\end{array}$ & $\mathrm{t}$ & $\mathrm{df}$ & $\mathrm{p}$ & $\begin{array}{c}\mathrm{N} \\
\mathrm{Fe}\end{array}$ & $\begin{array}{c}\mathrm{N} \\
\mathrm{Ma}\end{array}$ & $\begin{array}{c} \pm \mathrm{SD} \\
\mathrm{Fe}\end{array}$ & $\begin{array}{c} \pm \mathrm{SD} \\
\mathrm{Ma}\end{array}$ & $\begin{array}{c}\text { Quo- } \\
\text { tient }\end{array}$ & $\mathrm{p}(\mathrm{W})$ \\
$\mathrm{F}(\mathrm{W})$ & \\
\hline $\begin{array}{l}\text { Number of } \\
\text { points }\end{array}$ & 4.87 & 6.27 & -1.24 & 84 & 0.22 & 60 & 26 & 4.45 & 5.57 & 1.57 & 0.16 \\
\hline
\end{tabular}

Age category; expected marginal averages; current effect: $F(2.83)=6.5625, p=.00226$

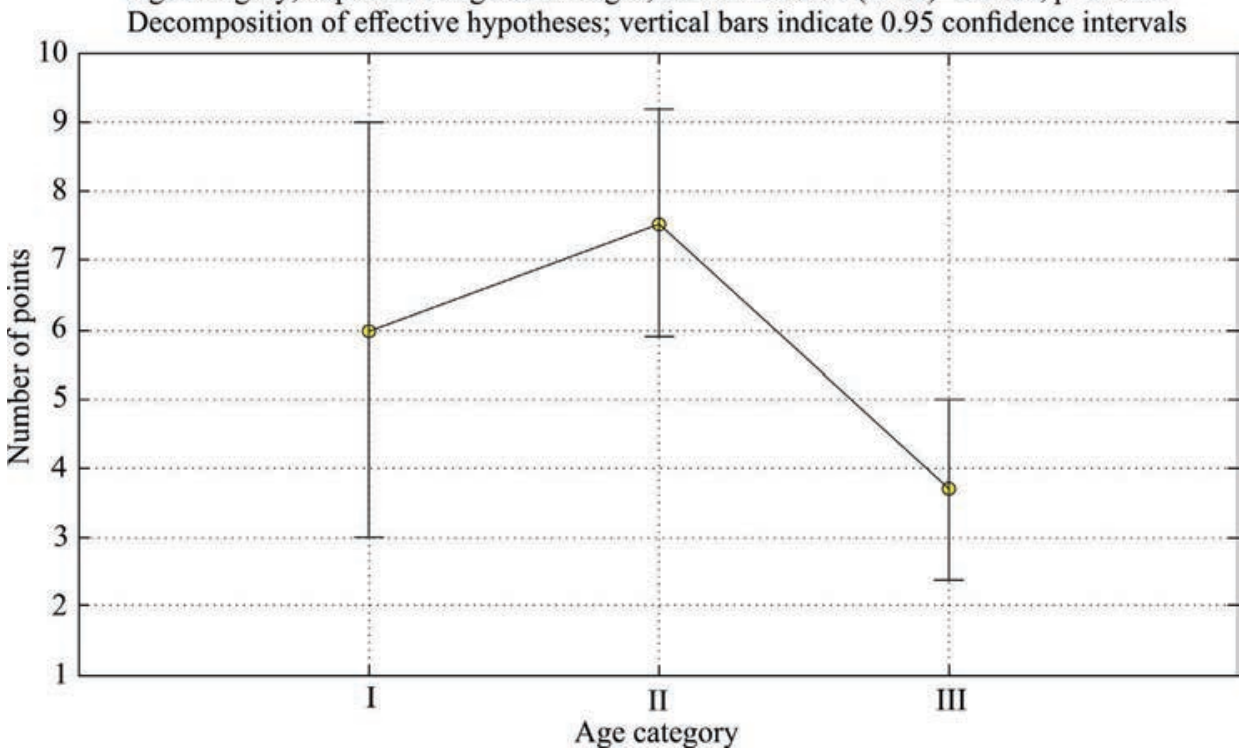

Fig. 3. Comparison of the average scoring of surveys on the care of diabetic foot in three age categories of respondents; I - from 30 to 50 years, II - from 51 to 70 , III - above 70

However, the average scores for the three age groups were 6.00 ( $\mathrm{SD} \pm 4.90)$ for age group I, 7.53 for group II (SD \pm 4.71$)$ and $3.72(\mathrm{SD} \pm 4.37$ ) for group III (Fig. 3; Tab. 3).

Tab. 3. The results of the parametric ANOVA test made to examine the significance of statistical differences between the average scores of respondents in the three age categories analysed; the differences were considered significant at $\mathrm{p} \leq 0.05$

\begin{tabular}{lccccc}
\hline & \multicolumn{5}{c}{ One-dimensional significance tests for "Number of points" } \\
\cline { 2 - 6 } Effect & SS & $\begin{array}{c}\text { Degrees } \\
\text { of freedom }\end{array}$ & MS & F & $\mathrm{p}$ \\
\hline Intercept & 1796.97 & 1 & 1796.97 & 87.079 & 0.000 \\
Age category & 270.86 & 2 & 135.43 & 6.562 & 0.002 \\
Error & 1712.87 & 83 & 20.64 & - & - \\
\hline
\end{tabular}


The ANOVA test, used to determine statistical significance in the average survey score, showed that there were differences between the compared age groups $(\mathrm{p}=$ 0.002). Tukey's post hoc test showed that these differences only applied to age groups III and II (Tab. 4).

Tab. 4. Tukey's post hoc test results regarding statistical significance between average scoring obtained in three age categories of respondents; I - from 30 to 50 years, II - from 51 to 70, III - above 70; the differences were considered significant at $\mathrm{p} \leq 0.05$

\begin{tabular}{|c|c|c|c|c|}
\hline \multirow{2}{*}{ No. } & \multicolumn{4}{|c|}{$\begin{array}{l}\text { Variable - 'Number of points'; approximate probabilities for post hoc tests; } \\
\text { error: MS intergroup }=20.637, \mathrm{df}=83 \text {; uneven N }\end{array}$} \\
\hline & Age category & $\begin{array}{c}\{1\} \\
3.723\end{array}$ & $\begin{array}{l}\{2\} \\
7.533\end{array}$ & $\begin{array}{c}\{3\} \\
6.000\end{array}$ \\
\hline 1. & I & 0.539 & 0.754 & \\
\hline 2. & II & 0.005 & & 0.755 \\
\hline 3. & III & & 0.005 & 0.539 \\
\hline
\end{tabular}

A comparison of the total score for individual questions by group, females and males, showed that the surveyed females remembered to dry the space between the fingers (56 points). They knew that important elements in avoiding the formation of diabetic foot are to control glucose, blood pressure and strive to maintain a healthy weight (55 points) and to check shoes (55 points) before wearing. They were aware that smoking can lead to earlier development of diabetic foot (55 points). However, the female respondents did not know that they should not cut nails with diabetic foot with metal clippers ( -55 points) or how many times a day they should change the dressings in the case of foot ulceration ( -55 points), etc. (Fig. $4 \mathrm{~A})$.

The same comparison in the male group revealed similar answers. Males also knew that controlling glucose, blood pressure and striving to maintain a healthy weight (24 points) are part of avoiding diabetic foot formation. In addition, they knew that after washing, it is best to dry your feet with a soft towel (24 points) and that they should purchase socks made only from natural fibres (22 points). Males, like females, did not know that they should not cut nails with diabetic foot with metal clippers ( -23 points) or that it is best to walk around the home in closed-toe slippers (-22 points) (Fig. 4B).

A comparison of the total score of the respondents by age group showed that, in age group I - i.e. 30 to 50 years old, respondents knew that after buying new shoes they should allow their feet to gradually become accustomed to them, by daily walking for 10-15 minutes, and that after washing it is best to dry feet with a soft towel. They were aware that controlling glucose and blood pressure and maintaining a healthy weight are important preventive elements in DFS. This group of respondents knew to dry the space between the toes and that they should not wear shoes on bare feet ( 9 points for all answers). However, they were not aware that people with DFS should not walk barefoot on the beach. They made the mistake of thinking that after buying new shoes, 
if there is skin abrasion, they should wait for healing and then the same shoes can worn again ( -9 points for all answers) (Fig. $5 \mathrm{~A}$ ).

In age group II - i.e. 51 to 70 years old, the respondents knew that only socks made from natural fibers should be purchased (28 points). Other results in this group were similar - i.e. respondents were aware of needing to control of glucose and blood pressure and maintain normal body weight in the prevention of diabetes (28 points), they knew that smoking can lead to earlier development of diabetic foot (28 points) and they knew that it is best to dry feet with a soft towel ( 26 points). They also remembered the need to dry the space between the toes ( 26 points). The weakest results for this group were for the questions: Is it good to use metal clippers to cut the nail plate? (-26 points), Should you walk in shoes with a soft sole at home? (-24 points), Is it good to walk around the home in open slippers? ( -24 points) and How many times can daily dressings be changed in the presence of fresh ulceration? (-24 points) (Fig. 5B).

In age group III - i.e. over 70 years of age, respondents knew that smoking can lead to an earlier development of DFS ( 45 points) and to check before putting on shoes that there was nothing in them (44 points). They were aware of needing to control glucose and blood pressure and maintaining normal body weight in diabetic prophylaxis (42 points). They performed most poorly on the questions: What is the best way to cut the nail plate? (-43 points), How many times a day can the dressing be changed if there is a fresh uncleration (-43 points), and Is it advisable to moisturise the space between the toes in a diabetic foot? ( -37 points) (Fig. 5C).

\section{Discussion}

The study results were used to illustrate the most common mistakes in DFS care among respondents of different genders and from different age ranges. There are research studies that point to the essentiality of prevention in the treatment of diabetic foot but they are from the point of view of the role of a diabetologist (e.g. Mrozikiewicz-Rakowska et al., 2013; Tatoń, 2014). To date, there are few studies that demonstrate the essential role of a podologist against the background of the real knowledge of respondents about feet care in DFS. Many diabetologists believe that early prevention of diabetic foot will prevent amputation of the lower limbs (Bernas, 2003; Valabhji et al., 2010; Holmanet al., 2012; Hoffstad et al., 2015). They agree that from the initial stages of diabetes the elimination of smoking, for example, is necessary, and that regular monitoring of basic diagnostic parameters important for diabetes is needed. An important role in this respect is served by, for example, foot exercises, careful skin care and controlling blood supply and innervation (Bowering, 2001; Boulton, 2006). 


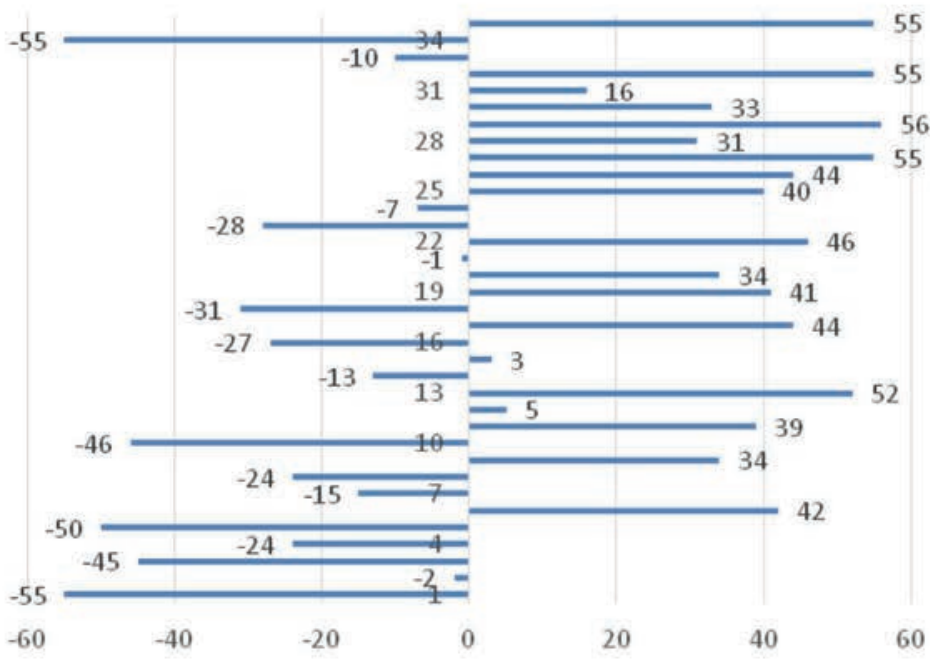

B

Total number of points

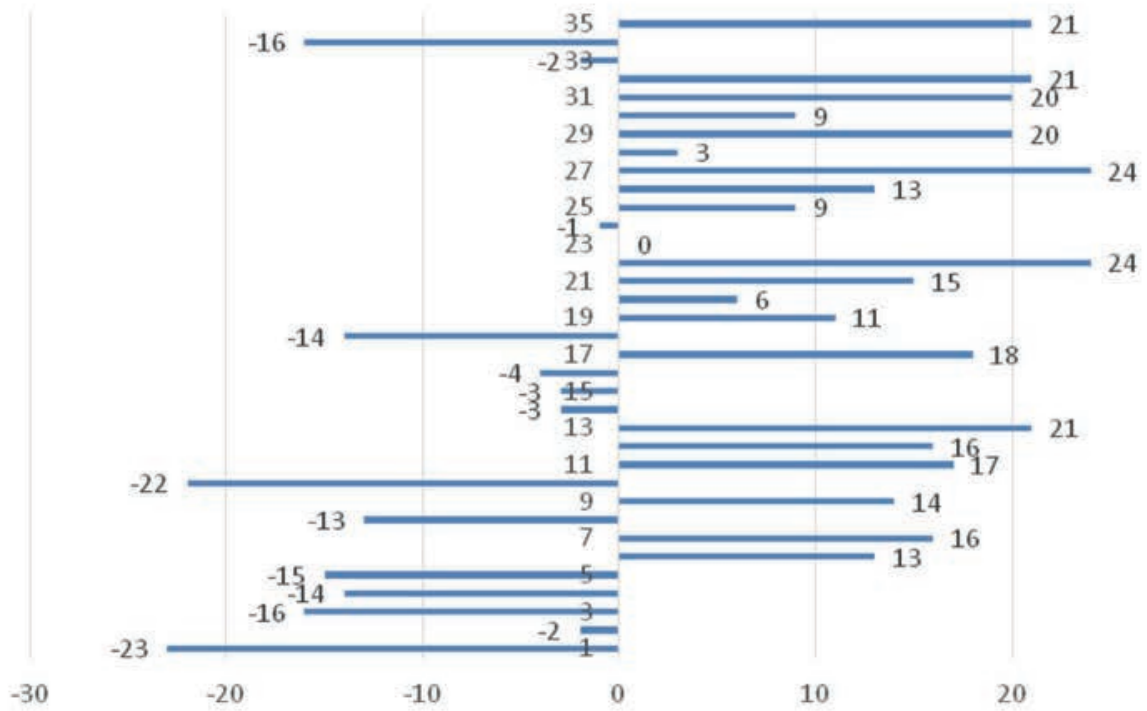

Fig. 4. Comparison of the total score obtained by respondents in the survey (1-35 question numbers) regarding diabetic foot care, for individual questions separately in groups of gender: $A)$ females $(N=60)$, B) males $(\mathrm{N}=26)$ 
Total number of points

A

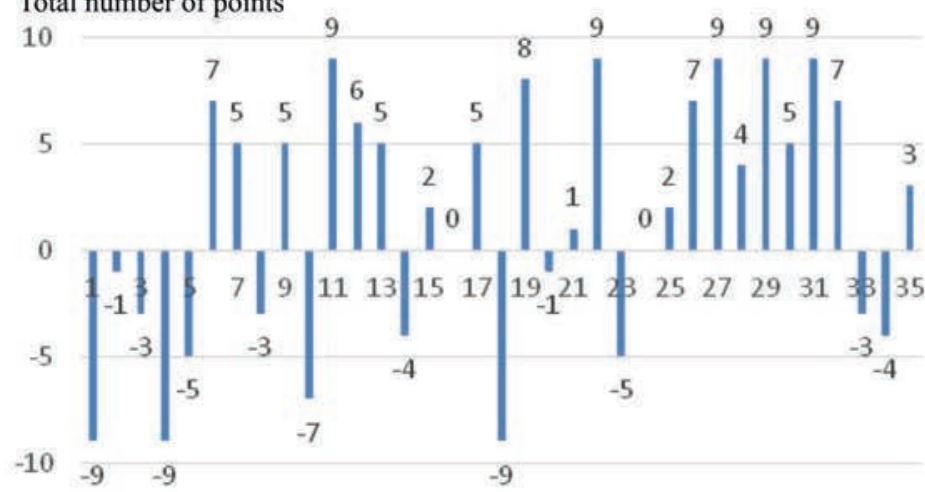

Total number of points

B

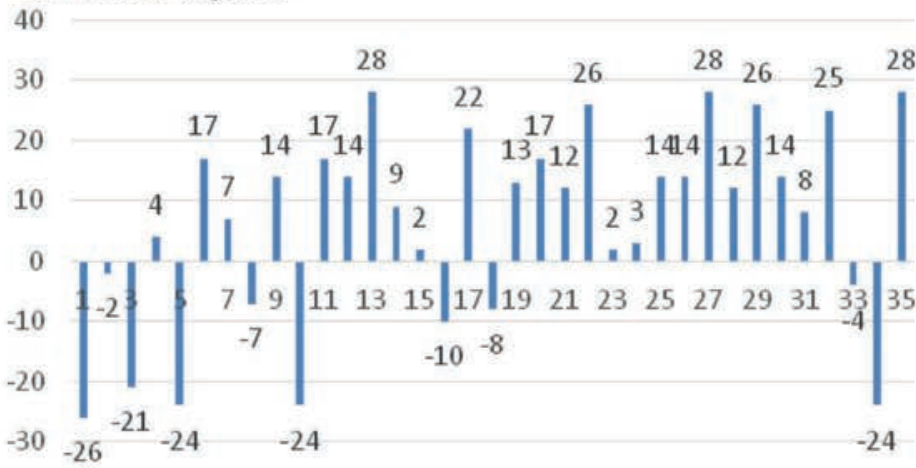

Total number of points

$\mathrm{C}$

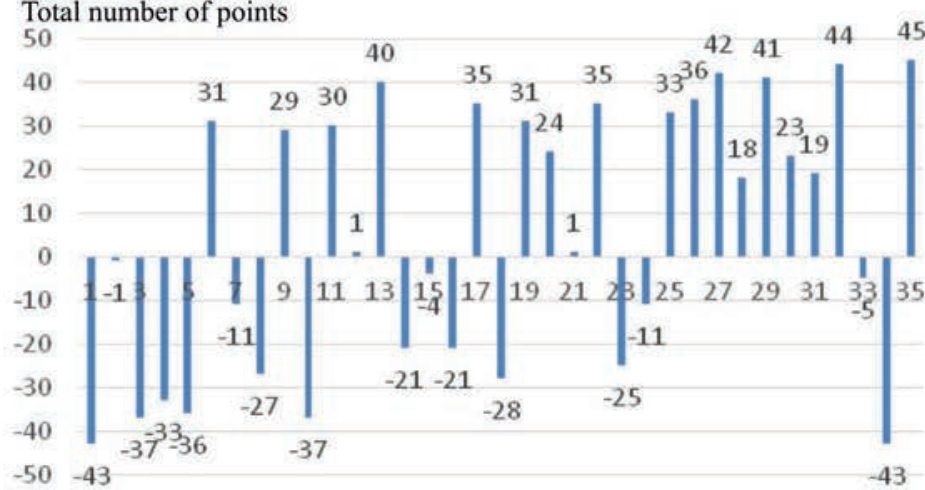

Fig. 5. Comparison of the total score obtained by respondents in the survey (1-35 question numbers) regarding diabetic foot care, for individual questions separately in groups of age: A) I - from 30 to 50 years $(\mathrm{N}=9), \mathrm{B})$ II - from 51 to $70(\mathrm{~N}=30), \mathrm{C}) \mathrm{III}$ - above $70(\mathrm{~N}=47)$ 
The survey showed that respondents were aware of the risk of smoking in diabetic disease ( $92 \%$ of respondents). They (77\% of respondents) also knew that gymnastics has a significant impact on foot health and that you need to regularly check your blood sugar and body weight (Tab. 2). The research also showed that respondents had some knowledge about foot care but in other respects it was insufficient, hence the need for more frequent visits to the podologist. When caring for nails, most respondents did not know that metal clippers cannot be used to cut nails (Tab. 2; Fig. 1, 4-5). In diabetic foot patients, even the smallest wounds can develop inflammation and even into ulcerations, leading, in extreme cases, to tissue necrosis (Margolis et al., 2002; Potaczek, 2005; Hoffstad et al., 2015). Respondents were not aware that, for ulcerations, the number of dressing changes depends on a doctor's recommendation; ulcerative conditions differ and should be treated strictly according to a doctor's instructions, especially for diabetic foot patients (Rosiński, Jasik, 2001; Catanese, 2002; Koblik, 2005; Głuszek et al., 2007; Wujczyk, 2007).

Another risk is the ignorance of respondents regarding the wearing of open-toe slippers in patients with diabetic foot. Open-toe slippers do not protect against various types of mechanical injuries, which are not always easy to avoid, and slippers should not be made of plastic materials because it makes ventilation difficult and promotes moisture between the toes. Similarly, a soft sole for home footwear is also not recommended (Koselak, 2014). Keeping foot skin healthy is very important for people with diabetes because their skin is more prone to cracking (Tatoń et al., 2008, 2013). Respondents knew about this issue and care for proper moisturisation of foot skin (Tab. 2; Fig. 1, 4-5). They knew that they need to dry the spaces between the toes because any humidity remaining there can be conducive to fungal infections, which are very common in DFS (Rosiński, Jasik, 2001; Catanese, 2002; Zieliński et al., 2014).

The survey showed that there were no statistically significant differences in the level of knowledge about the care of diabetic foot between females and males (Tab. 3; Fig. 2). Both males and females agreed that smoking can lead to earlier development of DFS (Fig. 4). They believed that controlling glucose and blood pressure and maintaining a healthy body weight are an important element in avoiding diabetic foot. They made similar mistakes for responses on the care of feet: they were not aware of what tool is the best for cutting nails, they moisturized the spaces between the toes with cream, they did not know how many times a day they should change dressings in the event of fresh ulcerations, etc. In this case, gender did not matter because DFS equally affects both females and males, although, as the study showed, females more often decided to visit a cosmetic salon and undergo podological consultations (Tab. 1). This is probably due to the fact that statistically more females than males have diabetes (King et al., 1998; Tatoń et al., 2013). 
The results of surveys among respondents divided into three age categories revealed many similarities but statistically significant differences were found between the age group II and age group III (Tab. 3-4; Fig. 3). Generally, the highest average score in the surveys was achieved by people from the age group II - from 51 to 70 years of age. Perhaps a greater interest in the care of diabetic foot at this age is due to the fact that this is the group in which diabetes most often begins to appear (Koselak, 2014; Benoit et al., 2020). They are middle-aged people, willing to independently oppose the effects of this disease. It is probable that people over 70 are less willing to perform foot care procedures on their own, hence their significantly lower level of knowledge on this topic (Fig. 5). Respondents from the 51-70 years age group proved that they are aware of basic recommendations in the prevention of diabetes, and the irregularities they commit are similar to those in other analysed age categories (Fig. 5A-C). People in the $30-50$ years age range did not know that with DFS there is an absolute contraindication for walking barefoot on the beach (Fig. 5A), due to the possibility of foot damage from shells. For similar reasons, it is impossible to wear the same shoes again after foot skin abrasions are caused by new footwear. This can quickly lead to a renewal of wounds, and with longer duration, and can be the cause of infection and difficult-to-heal ulcers (Rosiński, Jasik, 2001; Bernas, 2003). However, respondents from this age group knew that feet should become accustomed to new shoes and fee should be dried with a soft towel.

It can, therefore, be concluded that in the analysed statistical population many negligences in the care of diabetic foot could be avoided because they are primarily the result of lack of contact with a podologist. Of course, they can also be the result of a lack of interest in self-care for diabetic foot by respondents themselves. The basic task of a podologist is to implement care recommendations that protect patients from complications of DFS, but perhaps even more important is their function to make patients aware of the need for individual foot care (Świderska, 2012; Koselak, 2014). Such care is very important in the prevention of this age-old disease (Catanese, 2002; Tatoń, 2002; Tatoń et al., 2008, 2013; Zielińnki et al., 2014).

\section{Conclusion}

(1) Most respondents correctly believed that an important element in avoiding the formation of DFS is to control glucose and blood pressure and maintain a healthy weight; relatively poor knowledge was observed by all respondents concerning nail care and, in the case of ulcerations, how many times a day dressing should be made; there were no statistically significant differences in the level of knowledge about the care of diabetic foot between females and males; survey results in the age groups distinguished that respondents made similar mistakes in knowledge of the methods of 
care for the diabetic foot, and statistically significant differences were found for age categories II and III; the highest scores for knowledge of DFS care were achieved by people 51-70 years of age who want to perform foot skin care themselves. (2) The survey also showed that respondents made basic mistakes during foot care that could have been avoided if they had contacted a podologist; the role of the podologist is therefore not only to perform foot care procedures but to make patients aware and implement simple recommendations that will protect patients from complications.

\section{References}

Benoit, S.R., Hora, I., Pasquel, F.J., Gregg, E.W., Albright, A.L., Imperatore, G. (2020). Trends in emergency department visits and inpatient admissions for hyperglycemic crises in adults with diabetes in the U.S., 2006-2015. Diabetes Care, 43(5), 1057-1064. https://doi.org/10.2337/dc19-2449

Bernas, M. (2003). Patogeneza i klinika zespołu stopy cukrzycowej - współpraca z chirurgiem (Pathogenesis and the clinic of diabetic foot syndrome - cooperation with a surgeon). Przewodnik Lekarski, 6, 169-175. [In Polish]

Boucek, P. (2006). Advanced diabetic neuropathy: A point of no return? The Review of Diabetic Studies, 3, 143-150. https://doi.org/10.1900/RDS.2006.3.143

Boulton, A.J.M. (2006). The diabetic foot. Medicine, 34, 87-90. https://doi.org/10.1016/j. mpmed.2014.10.006

Boulton, A.J.M., Malik, R.A., Arezzo, J.C., Sosenko, N.J. (2004). Diabetic somatic neuropathies. Diabetes Care, 27, 1458-1486. https://doi.org/10.2337/diacare.27.6.1458

Bowering, C.K. (2001). Diabetic foot ulcers - pathophysiology, assessment, and therapy. Canadian Family Physician, 47, 1007-1010.

Catanese, V.M. (2002). Cukrzyca wtórna. Atlas diabetologii klinicznej (C.R. Kahn, S.G. Korenmanred) (Secondary diabetes. Atlas of Clinical Diabetology (C.R. Kahn, S.G. Korenmanred)). Gdańsk: Via Medica. [In Polish]

Czeleko, T., Śliwczyński, A., Nawrot, I., Karnafel, W. (2014). The incidence of major, nontraumatic lower amputations in patients without diabetes mellitus in Poland during 2009-2012, based on Polish National Health Found data. Acta Angiologica, 20(3), 124-131. [In Polish]

DiGiovani, Ch.W., Greisberg, J. (2010). Stopa i staw skokowo-goleniowy (Foot and ankle joint). In: W.J. Marczyński (ed.), Core Knowedge in Orthopaedies. Wrocław: Elsevier Urban Partner, s. 11-17. [In Polish]

Głuszek, S., Rączka, M., Zagórska, S. (2007). Stopa cukrzycowa jako trudny interdyscyplinarny problem kliniczny (Diabetic foot as a difficult interdisciplinary clinical problem). Medical Studies, 8, 61-66. [In Polish]

Holman, N., Young, R.J., Jeffcoate, W.J. (2012). Variation in the recorded incidence of amputation of the lower limb in England. Diabetologia, 55, 1919-1925. https://doi.org/10.1007/s00125-012-2468-6

Hoffstad, O., Mitra, N., Walsh, J., Margolis, D.J. (2015). Diabetes, lower-extremity amputation, and death. Diabetes Care, 38(10), 1852-1857. https://doi.org/10.2337/dc15-0536

Karvonen, M., Viik-Kajander, M., Molchanova, E., Libman, I., LaPorte, R., Tuomilehto, J. (2000). Incidence of childhood type 1 diabetes worldwide. Diabetes Mondiale (DiaMond) Project Group. Diabetes Care, 23, 1516-1526. https://doi.org/10.2337/diacare.23.10.1516

Kasperczyk, T. (2004). Wady postawy ciała. Diagnostyka i leczenie (Body posture defects. Diagnostics and treatment). Kraków: Kasper. [In Polish] 
King, H., Albert, R., Herman, W. (1998). Global burden of diabetes 1995-2025, Prevalence, numerical estimates and projections. Diabetes Care, 21, 1414-1031. https://doi.org/10.2337/diacare.21.9.1414

Koblik, T. (2005). Zespół stopy cukrzycowej (Diabetic foot syndrome). Lek w Polsce, 4, 54-61. [In Polish]

Koblik, T. (2008). Wczesne wykrywanie stopy cukrzycowej (Early detection of the diabetic foot). Diabetologia Praktyczna, 9, 48-53. [In Polish]

Koselak, M. (2014). Podstawy podologii kosmetycznej (Basics of cosmetic podology). Warszawa: Wydawnictwo Wyższej Szkoły Zawodowej Kosmetyki i pielęgnacji Zdrowia. [In Polish]

Kozek, E. (2002). Choroba wieńcowa u chorych na cukrzycę - odrębności kliniczne (Coronary artery disease in diabetic patients - clinical differences). Diabetologia Praktyczna, 4, 197-211. [In Polish]

Levy, M., Valabhji, J. (2008). The diabetic foot. Surgery, 26(1), 25-28.

Margolis, D.J., Hoffsad, O., Allen-Taylor, L. Berlin, J.A. (2002). Owrzodzenie stopy w przebiegu neuropatii cukrzycowej (Foot ulcer in the course of diabetic neuropathy). Diabetologia Praktyczna, 4, 266-267. [In Polish]

Mrozikiewicz-Rakowska, B., Krasnodębski, P., Jasik, M, Dębe, K., Karnafel, W. (2013). Rola diabetologa w profilaktyce zespołu stopy cukrzycowej (The role of a diabetologist in the prevention of diabetic foot syndrome). Medycyna Metaboliczna, 7(4), 69-73. [In Polish]

Potaczek, D.P. (2005). Rozpoznanie i leczenie zakażeń stopy cukrzycowej (Diagnosis and treatment of diabetic foot infections). Medycyna Praktyczna, 8, 117-155. [In Polish]

Rosiński, G., Jasik, M. (2001). Zespół stopy cukrzycowej (Diabetic foot syndrome). Terapia, 4, 24-26. [In Polish]

Świderska, K. (2012). Diagnostyka stóp w podologii - wybrane metody (Foot diagnostics in podiatry selected methods). Kosmetologia Estetyczna, 3, 220-223. [In Polish]

Tatoń, J. (2002). Postępowanie w cukrzycy typu 2 oparte na dowodach (Evidence-based management of type 2 diabetes). Warszawa: PZWL, p. 11-133. [In Polish]

Tatoń, J. (2014). „Komu bije dzwon” ryzyka cukrzycy? Szanse i zaniedbania w profilaktyce cukrzycy typu 2 ("Who is the bell for" diabetes risk? Opportunities and negligence in the prevention of type 2 diabetes). Medycyna Metaboliczna, 18(1), 19-29. [In Polish]

Tatoń, J., Czech, A., Bernas, M. (2008). Diabetologia kliniczna (Clinical diabetology). Warszawa: PZWL. [In Polish]

Tatoń, J., Czech, A., Bernas, M., Biernacka, E. (2013). Socjologia cukrzycy (Diabetes sociology). Łódź: Eskulap. [In Polish]

Tuttolomondo, A., Maida, C., Pinto, A. (2015). Diabetic foot syndrome: Immune-inflammatory features as possible cardiovascular markers in diabetes. World Journal of Orthopedics, 6(1), 62-76. https://doi. org/10.5312/wjo.v6.i1.62

Valabhji, J., Gibbs, R.G.J., Bloomfield, L., Lyons, S., Samarasinghe, D., Rosenfeld, P., Gabriel, C.M., Hogg, D., Bicknell, C.D. (2010). Matching the numerator with an appropriate denominator to demonstrate low amputation incidence associated with a London hospital multidisciplinary diabetic foot clinic. Diabetic Medicine, 27, 1304-1307. https://doi.org/10.1111/j.1464-5491.2010.03104.x

Wujczyk, M. (2009). Stopa cukrzycowa (Diabetic foot). Portal Zdrowia PZWL. http: //www.forumzdrowia. pl. [In Polish]

Zieliński, E., Grobelska, K., Telak, J., Galarowicz, O., Kaczerska, D., Lipińska, A. (2014). Zespół stopy cukrzycowej jako istotny problem terapeutyczny i ekonomiczny (Diabetic foot syndrome as a significant therapeutic and economic problem). Polish Hyperbaric Research, 3(48), 7-18. [In Polish] 
Educational survey - diabetic foot syndrome (template)

\begin{tabular}{|c|c|c|c|c|}
\hline \multicolumn{5}{|c|}{$\begin{array}{l}\text { Below are } 35 \text { terms for foot care. } \\
\text { Please assess their correctness by putting a cross in the appropriate box - YES, NO or I DON'T } \\
\text { KNOW }\end{array}$} \\
\hline No. & Ascertainment & YES & NO & $\begin{array}{l}\text { I DON'T } \\
\text { KNOW }\end{array}$ \\
\hline 1. & It is best to use metal clippers to cut the nail plate & & & \\
\hline 2. & Feet should be washed at temperatures above $37^{\circ} \mathrm{C}$ & & & \\
\hline 3. & $\begin{array}{l}\text { After washing, moisturising cream should be to applied to } \\
\text { your feet between your toes }\end{array}$ & & & \\
\hline 4. & It is best to walk barefoot on the beach & & & \\
\hline 5. & At home, one should walk in shoes with a soft sole & & & \\
\hline 6. & $\begin{array}{l}\text { Gymnastics (pre-planned exercises performed 2-3 times a } \\
\text { week) has a significant impact on foot health }\end{array}$ & & & \\
\hline 7. & Toes nails should be cut as short as possible & & & \\
\hline 8. & $\begin{array}{l}\text { Feet should be washed very thoroughly and soaked in a bowl } \\
\text { for at least } 15 \text { minutes }\end{array}$ & & & \\
\hline 9. & $\begin{array}{l}\text { In case of excessive sweating of the feet, talcum powder } \\
\text { should be used }\end{array}$ & & & \\
\hline 10. & It is best to walk around the home in open-toe slippers & & & \\
\hline 11. & $\begin{array}{l}\text { After buying new shoes, a foot should gradually get used to } \\
\text { them, by daily walking for } 10-15 \text { minutes }\end{array}$ & & & \\
\hline 12. & Plaster is the best dressing to feet ulceration & & & \\
\hline 13. & $\begin{array}{l}\text { Socks, tights made only of natural fibres (cotton) should be } \\
\text { purchased; wool socks should be avoided }\end{array}$ & & & \\
\hline 14. & The nails should be cut without rounding on the sides & & & \\
\hline 15. & Hydro massagers should be used for foot massage & & & \\
\hline 16. & Intensive moisturising creams should not be used & & & \\
\hline 17. & The best shoes are natural leather, no seams inside & & & \\
\hline 18. & $\begin{array}{l}\text { If there is a skin abrasion after buying new shoes, you should } \\
\text { wait for healing and wear them again }\end{array}$ & & & \\
\hline 19. & You should inform your doctor about any feet ulceration & & & \\
\hline 20. & $\begin{array}{l}\text { You should limit physical activity associated with direct im- } \\
\text { pact on feet }\end{array}$ & & & \\
\hline 21. & $\begin{array}{l}\text { To remove nail cuticles, you should use special preparations } \\
\text { to dissolve them }\end{array}$ & & & \\
\hline 22. & You should dry the feet with a soft towel after washing & & & \\
\hline 23. & You should remove layered hard skin by yourself & & & \\
\hline 24. & $\begin{array}{l}\text { Shoes should be purchased in the morning when the foot is } \\
\text { rested }\end{array}$ & & & \\
\hline 25. & Always measure your foot before buying shoes & & & \\
\hline 26. & The feet should be examined daily & & & \\
\hline
\end{tabular}




\begin{tabular}{|c|c|c|}
\hline 27. & $\begin{array}{l}\text { An important element to avoid the formation of diabetic foot } \\
\text { is to control glucose and blood pressure and strive to maintain } \\
\text { a healthy weight }\end{array}$ & \\
\hline 28. & Using a file, your nails should be filed in one direction & \\
\hline 29. & $\begin{array}{l}\text { You should remember to thoroughly dry the space between } \\
\text { your toes }\end{array}$ & \\
\hline 30. & To warm feet, hot water bottles should be used & \\
\hline 31. & It is advisable to wear shoes with bare feet & \\
\hline 32. & $\begin{array}{l}\text { Before wearing on shoes, you should make sure that there is } \\
\text { nothing in them (sand, stones, small items) }\end{array}$ & \\
\hline 33. & $\begin{array}{l}\text { The most important thing when checking your feet is to check } \\
\text { the dorsal parts }\end{array}$ & \\
\hline 34. & $\begin{array}{l}\text { If a fresh ulceration occurs, dressings should be changed twice } \\
\text { a day }\end{array}$ & \\
\hline 35. & $\begin{array}{l}\text { Smoking can lead to earlier development of diabetic foot syn- } \\
\text { drome }\end{array}$ & \\
\hline
\end{tabular}

Gender: Female Male..........

Please circle the age range: $30-50$ years old, $51-70$ years old, over 70 years old. 
Summary survey table

Comparison of the number and percentage of "correct", "incorrect" and "don't know" answers given by 86 respondents to the questionnaire regarding diabetic foot care; bold has the highest percentage of responses

\begin{tabular}{|c|c|c|c|c|c|c|}
\hline \multirow{2}{*}{$\begin{array}{c}\text { No. of } \\
\text { question in } \\
\text { survey }\end{array}$} & \multicolumn{2}{|c|}{ Correct answers } & \multicolumn{2}{|c|}{ Incorrect answers } & \multicolumn{2}{|c|}{$\begin{array}{l}\text { No answer - } \\
\text { "don't know" }\end{array}$} \\
\hline & Numerically & {$[\%]$} & Numerically & [\%] & Numerically & {$[\%]$} \\
\hline 1 & 0 & 0 & 78 & 91 & 8 & 9 \\
\hline 2 & 35 & 41 & 39 & 45 & 12 & 14 \\
\hline 3 & 11 & 13 & 72 & 84 & 3 & 3 \\
\hline 4 & 24 & 28 & 62 & 72 & 0 & 0 \\
\hline 5 & 3 & 4 & 69 & 80 & 14 & 16 \\
\hline 6 & 66 & 77 & 11 & 13 & 9 & 10 \\
\hline 7 & 39 & 45 & 38 & 44 & 9 & 11 \\
\hline 8 & 17 & 20 & 54 & 63 & 15 & 17 \\
\hline 9 & 63 & 73 & 15 & 18 & 8 & 9 \\
\hline 10 & 8 & 9 & 76 & 89 & 2 & 2 \\
\hline 11 & 62 & 72 & 6 & 7 & 18 & 21 \\
\hline 12 & 41 & 48 & 20 & 23 & 25 & 29 \\
\hline 13 & 77 & 89 & 4 & 5 & 5 & 6 \\
\hline 14 & 27 & 31 & 43 & 50 & 16 & 19 \\
\hline 15 & 19 & 22 & 19 & 22 & 48 & 56 \\
\hline 16 & 12 & 14 & 43 & 50 & 31 & 36 \\
\hline 17 & 70 & 82 & 8 & 9 & 8 & 9 \\
\hline 18 & 20 & 23 & 65 & 76 & 1 & 1 \\
\hline 19 & 61 & 71 & 9 & 10 & 16 & 19 \\
\hline 20 & 48 & 56 & 8 & 9 & 30 & 35 \\
\hline 21 & 25 & 29 & 19 & 22 & 42 & 49 \\
\hline 22 & 78 & 91 & 8 & 9 & 0 & 0 \\
\hline 23 & 27 & 31 & 55 & 64 & 4 & 5 \\
\hline 24 & 32 & 37 & 40 & 47 & 14 & 16 \\
\hline 25 & 60 & 70 & 11 & 13 & 15 & 17 \\
\hline 26 & 70 & 81 & 13 & 15 & 3 & 4 \\
\hline 27 & 81 & 94 & 2 & 2 & 3 & 4 \\
\hline 28 & 42 & 49 & 8 & 9 & 36 & 42 \\
\hline 29 & 78 & 91 & 2 & 2 & 6 & 7 \\
\hline 30 & 54 & 63 & 12 & 14 & 20 & 23 \\
\hline 31 & 60 & 70 & 24 & 28 & 2 & 2 \\
\hline 32 & 80 & 93 & 4 & 5 & 2 & 2 \\
\hline 33 & 14 & 16 & 26 & 30 & 46 & 54 \\
\hline 34 & 1 & 1 & 72 & 84 & 13 & 15 \\
\hline 35 & 79 & 92 & 3 & 3 & 4 & 5 \\
\hline
\end{tabular}




\section{Profilaktyka i pielęgnacja stopy cukrzycowej - ocena kompetencji respondentów}

Streszczenie

W roku 2015 przeprowadzono badania wśród 86 klientów losowo wybranego gabinetu kosmetycznego w Krakowie (Południowa Polska). Celem pracy była ocena wiedzy respondentów na temat pielęgnacji i profilaktyki stopy cukrzycowej. Dodatkowym celem było wskazanie roli podologa w profilaktyce chorób stóp. Grupę badawczą stanowiło 36 kobiet oraz 26 mężczyzn powyżej siedemdziesięciu lat, 19 kobiet i 14 mężczyzn w przedziale wiekowym od 51-70 lat i 6 kobiet 3 mężczyzn w przedziale wiekowym od 30-50 lat. Przeprowadzona ankieta była anonimowa i składała się z 35 pytań. Dotyczyła wiedzy na temat pielęgnacji stóp: ich sposobu mycia, nawilżania, masowania, obcinania paznokci, usuwania nawarstwionego naskórka, używanego obuwia, a także świadomości kontroli podstawowych parametrów, ważnych w profilaktyce cukrzycy. Badania pokazały, iż respondenci podczas pielęgnacji stóp popełniają podstawowe błędy, których można byłoby uniknąć w przypadku kontaktu z podologiem. Najbardziej zainteresowaną grupą w samodzielnej pielęgnacji stóp okazali się chorzy z przedziału 51-70 lat, którzy mieli stosunkowo największą wiedzę na ten temat. Ankieta pokazała, że rola podologa polega na uświadomieniu i wdrożeniu u pacjenta prostych zaleceń, które uchronią go przed powikłaniami oraz nauczą właściwej pielęgnacji kończyn dolnych w zespole stopy cukrzycowej.

Key words: diabetic foot syndrome (DFS), podology, questionnaire method

Received: [2020.03.28]

Accepted: [2020.05.18] 